\title{
Effect of Bacterial or Fungal Phytase Supplementation on the Performance, Egg Quality, Plasma Biochemical Parameters, and Reproductive Morphology of Laying Hens
}

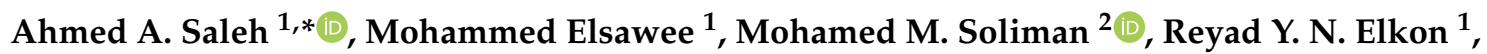

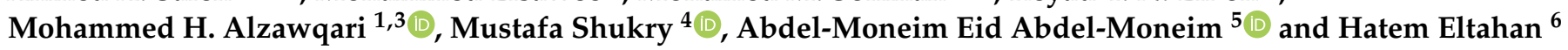 \\ check for \\ updates \\ 1 Department of Poultry Production, Faculty of Agriculture, Kafrelsheikh University, \\ Kafrelsheikh 333516, Egypt; mfayd222@gmail.com (M.E.); reyadnofal@agr.kfs.edu.eg (R.Y.N.E.); \\ m.alzawqari@gmail.com (M.H.A.) \\ 2 Clinical Laboratory Sciences Department, Turabah University College, Taif University, \\ Taif 21944, Saudi Arabia; mmsoliman@tu.edu.sa \\ 3 Department of Animal Production, Faculty of Agriculture and Veterinary Medicine, Ibb University, \\ Ibb 70270, Yemen \\ 4 Department of Physiology, Faculty of Veterinary Medicine, Kafrelsheikh University, \\ Kafrelsheikh 33511, Egypt; mostafa.ataa@vet.kfs.edu.eg \\ 5 Biological Application Department, Nuclear Research Center, Egyptian Atomic Energy Authority, \\ Abu-Zaabal 13759, Egypt; aeabdelmoneim@gmail.com \\ 6 Animal Production Research Institute, Agricultural Research Center, Ministry of Agriculture, \\ Dokki 12622, Egypt; hatem_eltahan2002@yahoo.com \\ * Correspondence: ahmed.saleh1@agr.kfs.edu.eg
}

Citation: Saleh, A.A.; Elsawee, M.; Soliman, M.M.; Elkon, R.Y.N.; Alzawqari, M.H.; Shukry, M.; Abdel-Moneim, A.-M.E.; Eltahan, H. Effect of Bacterial or Fungal Phytase Supplementation on the Performance, Egg Quality, Plasma Biochemical Parameters, and Reproductive Morphology of Laying Hens. Animals 2021, 11, 540. https://doi.org/ 10.3390/ani11020540

Academic Editor: Cormac O'Shea Received: 5 February 2021

Accepted: 17 February 2021

Published: 19 February 2021

Publisher's Note: MDPI stays neutral with regard to jurisdictional claims in published maps and institutional affiliations.

Copyright: (C) 2021 by the authors. Licensee MDPI, Basel, Switzerland. This article is an open access article distributed under the terms and conditions of the Creative Commons Attribution (CC BY) license (https:// creativecommons.org/licenses/by/ $4.0 /)$.
Simple Summary: The present study shows that 5000 FTU/kg dietary supplementation with bacterial (E. coli) or fungal (Aspergillus niger and Trichodermareesei) sources of phytase with less available phosphorus is capable of maintaining productive efficiency, reproductive morphology, and egg quality of laying hens. Eggshell consistency was increased while yolk cholesterol was decreased as a result of diets supplemented with bacterial or fungal phytase. All in all, our results clarify that feeding laying hens bacterial and fungal phytase at $5000 \mathrm{FTU} / \mathrm{kg}$ can be effective to replace inorganic phosphorus commercially.

Abstract: Catalytic and physicochemical properties of microbial phytase sources may differ, affecting phosphorus $(\mathrm{P})$ release and subsequently the productive and reproductive performance of layers. The current study aimed to evaluate the impact of bacterial and fungal phytase sources on layer productivity, egg production, biochemical blood indices, and reproductive morphology. For this purpose, 360 Bovans brown hens at 42 weeks of age were randomly allocated into 4 experimental groups, each with 15 replicates of 6 hens. The first group (control) was fed a basal diet with $4.6 \mathrm{~g} / \mathrm{kg}$ available P. In contrast, the second, third, and fourth groups were fed diets treated with $3.2 \mathrm{~g} / \mathrm{kg}$ available P, supplemented with either $5000 \mathrm{FTU} / \mathrm{kg}$ of bacterial E. coli (Quantum ${ }^{\mathrm{TM}}$ Blue 5G), fungal Aspergillus niger (VemoZyme ${ }^{\circledR}$ F 5000 Naturally Thermostable Phytase (NTP)), or fungal Trichodermareesei (Yemzim ${ }^{\circledR}$ FZ100). Dietary supplementation of bacterial and fungal phytases did not affect the productive performance or egg quality criteria, except for increased shell weight and thickness $(p<0.05)$. Serum hepatic function biomarkers and lipid profiles were not altered in treated hens, while calcium and $P$ levels were increased $(p<0.05)$ related to the controls. Ovary index and length, and relative weight of oviduct and its segments were not influenced. The contents of cholesterol and malondialdehyde in the yolks from treated birds were lower compared to control hens, while calcium and $\mathrm{P}$ content increased $(p<0.05)$. Conclusively, bacterial and fungal phytase sources can compensate for the reduction of available P in layers' diets and enhance shell and yolk quality without affecting productive performance, and no differences among them were noticed.

Keywords: phytase sources; performance; egg quality; blood biochemical parameters; reproductive morphology; layers 


\section{Introduction}

Phosphorus $(\mathrm{P})$ is an essential and vital nutrient that is well expressed in the components used in the formulation of feed for poultry production, mainly soybean meal or maize. Nevertheless, two-thirds of the total phosphate content in plant seeds is stored as phytate $\mathrm{P}$ and excreted without being digested $[1,2]$. Phosphorus phytate is poorly absorbed in the gastrointestinal tract of monogastric animals and can additionally negatively affect the digestibility of other nutrients and poultry performance due to its anti-nutritional impact [3,4]. Although sources of inorganic $\mathrm{P}$, such as dicalcium phosphate, can be added to poultry diets, this will increase the amount of released $P$ in the manure. Contamination of water with excessive $P$ leads to its eutrophication and subsequent enrichment of surface water with phytonutrients, which is considered a form of pollution [5]. This problem has motivated scientists to search for suitable ways to decrease the quantity of P excreted in poultry waste, and among these solutions is including phytase in the diet.

In the past few decades, the development of exogenous phytases has been considered one of the most significant findings in poultry nutrition. Exogenous phytases can eliminate the anti-nutritional effect of phytate, allow for better use of $\mathrm{P}$ and calcium $(\mathrm{Ca})$, enhance nutrient digestibility, and reduce environmental pollution by $\mathrm{P}$ by reducing its excretion in manure $[6,7]$. Dietary supplementation with exogenous phytases can reduce the required amount of non-phytic $P$. This elevates the amount of hydrolyzed phytate $P$ available to birds by hydrolyzing the phosphodiester bonds of phytates [8]. Phytases are classified into two subclasses, 3-phytase or 6-phytase, based on the position of the first hydrolyzed phosphate group on the myo-inositol ring [9]. They can also be organized as bacterial or fungal depending on their industrial production process or the microorganisms used as gene donors [10]. Commercially, several types of phytase are available; some are derived from fungi such as Aspergillus niger and A. ficum, which are generally 3-phytase (EC 3.1.3.8), and others are derived from the bacterium Escherichia coli or the fungi Peniphoralycii and Trichodermareesei, which are 6-phytases (EC 3.1.3.26) [10,11]. Furthermore, the microbial physicochemical and catalytic properties of phytases can differ [12], which can affect $P$ release and subsequently affect the productive and reproductive performance of laying hens. The catalytic properties of phytases differ based on their type: 3-phytases begin the degradation of phytate at position 3, while 6-phytases initiate the release of phosphate radicals in the $\mathrm{C} 6$ position of myo-inositol hexaphosphate $[10,11]$. Moreover, phytase sources may have different characteristics, such as thermal stability, resistance to degradation in the gastrointestinal tract, and $\mathrm{pH}$ required for optimal activity [12], which in turn affect the in vivo efficiency of phytase products. In order to assess the efficacy of the new phytases, ongoing studies are required.

To our knowledge, few studies have investigated the impact of bacterial or fungal phytases on laying hens. Therefore, this experiment aims to evaluate the impact of bacterial or fungal phytase sources on productive efficiency, egg quality, biochemical blood indices, and ovary formation in layers.

\section{Materials and Methods}

\subsection{Ethical Statement}

This study was conducted under the approval of the Ethics Committee of the Local Experimental Animals Treatment Committee and operated following the guidelines of Kafrelsheik University, Egypt (number 4/2016EC).

\subsection{Birds and Experimental Diets}

For the experiment, 360 Bovans brown hens (42 weeks of age, $86 \%$ egg production) were caged $\left(105 \times 65 \times 50 \mathrm{~cm}^{3}\right.$ (length $\times$ width $\times$ height) $)$ in an open-sided building, divided into 4 experimental groups, each with 15 replicates (6 hens/replicate) and under a 16:8 $\mathrm{h}$ light:dark lighting regimen with the same environmental management conditions (temperature, moisture, ventilation). Each cage was equipped with stainless steel nipple drinkers providing drinking water ad libitum. Feed in mash form was also offered ad 
libitum and the ambient temperature ranged between 24 and $27^{\circ} \mathrm{C}$. The first treatment group was fed the basal diet, which contained $4.6 \mathrm{~g} / \mathrm{kg}$ available $\mathrm{P}$, as control; the second, third, and fourth treatment groups were fed diets that included $3.2 \mathrm{~g} / \mathrm{kg}$ available $\mathrm{P}$, supplemented with $5000 \mathrm{FTU} / \mathrm{kg}$ diet of bacterial phytase (Quantum ${ }^{\mathrm{TM}}$ Blue 5G, AB-Vista, Plantation, FL, USA), fungal phytase (VemoZyme ${ }^{\circledR}$ F 5000 NTP, VEMO 99 Ltd., Sofia, Bulgaria), or fungal phytase (Yemzim ${ }^{\circledR}$ FZ100, OrbaBiokimya, Istanbul, Turkey). The first phytase source was derived from E. coli (6-phytase; EC 3.1.3.26), while the second and third phytase sources were derived from Aspergillus niger (3-phytase; EC 3.1.3.8) and Trichodermareesei (6-phytase; EC 3.1.3.26), respectively. Each phytase source contained 5000 phytase units (FTU) $/ \mathrm{kg}$ as described by the manufacturer's manual, moreover, the three enzymes are thermally stable and the activity recover more than $100 \%$ in mash feed 95-99\% in pelleted feed; the single unit corresponds to the enzyme quantity needed to liberate $1 \mu \mathrm{mol}$ of inorganic $\mathrm{P}$ from $5.1 \mathrm{mM}$ sodium phytate/minute at $37^{\circ} \mathrm{C}$ and $\mathrm{pH}$ 5.5 [13]. The composition of the experimental diet is presented in Table 1. Diets were determined to follow the guidelines for Bovans brown layers [14].

Table 1. Composition and nutrients of experimental diets.

\begin{tabular}{|c|c|c|c|c|}
\hline \multirow{2}{*}{ Ingredient, $\mathrm{g} / \mathrm{kg}$} & \multicolumn{4}{|c|}{ Dietary Phytase, g/kg * } \\
\hline & Control & Quantum $^{\mathrm{TM}}$ Blue 5G & VemoZyme $^{\circledR}$ F 5000 NTP & Yemzim ${ }^{\circledR}$ FZ100 \\
\hline Yellow corn & 606 & 608 & 608 & 608 \\
\hline Soybean meal, $46 \%$ & 203 & 205 & 205 & 205 \\
\hline Corn gluten meal, $62 \%$ & 62 & 60 & 60 & 60 \\
\hline Soybean oil & 5 & 5 & 5 & 5 \\
\hline Dicalcium phosphate & 15 & 9 & 9 & 9 \\
\hline DL-methionine, $99 \%$ & 1 & 1 & 1 & 1 \\
\hline L-lysine, $98 \%$ & 1.25 & 1.25 & 1.25 & 1.25 \\
\hline Limestone & 95 & 99 & 99 & 99 \\
\hline $\mathrm{NaCl}$ & 2.75 & 2.75 & 2.75 & 2.75 \\
\hline Premix ${ }^{1}$ & 3 & 3 & 3 & 3 \\
\hline Sodium bicarbonate & 1.25 & 1.25 & 1.25 & 1.25 \\
\hline Potassium carbonate & 4.5 & 4.5 & 4.5 & 4.5 \\
\hline Antitoxin ${ }^{2}$ & 0.25 & 0.25 & 0.25 & 0.25 \\
\hline \multicolumn{5}{|l|}{ Calculated nutrient ${ }^{3}$} \\
\hline Crude protein, \% & 17.49 & 17.49 & 17.49 & 17.49 \\
\hline $\mathrm{ME}, \mathrm{Kcal} / \mathrm{kg}$ diet & 2851 & 2851 & 2851 & 2851 \\
\hline Calcium, \% & 3.26 & 3.26 & 3.26 & 3.26 \\
\hline Total phosphorus, \% & 0.71 & 0.57 & 0.57 & 0.57 \\
\hline Available phosphorus, \% & 0.46 & 0.32 & 0.32 & 0.32 \\
\hline Phytate phosphorus, \% & 0.25 & 0.25 & 0.25 & 0.25 \\
\hline Ether extract, $\%$ & 4.46 & 4.46 & 4.46 & 4.46 \\
\hline Crude Fiber, \% & 2.80 & 2.80 & 2.80 & 2.80 \\
\hline Lysine, $\%$ & 0.88 & 0.88 & 0.88 & 0.88 \\
\hline Methionine, $\%$ & 0.49 & 0.49 & 0.49 & 0.49 \\
\hline Methionine + cysteine, $\%$ & 0.771 & 0.771 & 0.769 & 0.770 \\
\hline Threonine, $\%$ & 0.66 & 0.66 & 0.66 & 0.66 \\
\hline
\end{tabular}

${ }^{1}$ Premix content: vitamin mineral premix (units per kilogram of feed): vitamin A, 10,000 IU; vitamin D3, 3,500 IU; vitamin E, 35 IU; menadione, $1.5 \mathrm{mg}$; riboflavin, $5 \mathrm{mg}$; pantothenic acid, $8 \mathrm{mg}$; vitamin B12, $0.012 \mathrm{mg}$; pyridoxine, $1.5 \mathrm{mg}$; thiamine, $1.5 \mathrm{mg}$; folic acid, $0.5 \mathrm{mg}$; niacin, $30 \mathrm{mg}$; biotin, $0.06 \mathrm{mg}$; iodine, $0.8 \mathrm{mg}$; copper, $10 \mathrm{mg}$; iron, $80 \mathrm{mg}$; selenium, $0.3 \mathrm{mg}$; manganese, $80 \mathrm{mg}$; zinc, $80 \mathrm{mg}$. ${ }^{2}$ Calculated according to guidelines for brown Bovans laying hens [14]. 2Antitoxin; Hydrated sodium calcium aluminosilicates (HSCAS); ${ }^{3}$ Calculated according to ingredients composition provided by National Research Council (1994). * Control diet was not supplemented with phytase; other diets were supplemented with phytase sources at $100 \mathrm{mg}$ phytase $/ \mathrm{kg}$ diet. The enzymes activities are $100 \%$ recovered according to feed analyzed by the three enzymes companies' methods of analysis the phytase activity. NTP: Naturally Thermostable Phytase.

\subsection{Performance}

At the beginning ( 42 weeks old) and the end (54 weeks old) of the experiment, the body weight (BW) of birds was recorded. Eggs were collected daily, weighed individually, and used for all experimental periods to measure mean egg weight. Egg mass was determined by multiplying the production of eggs (\% hens/day) by the egg weights. Daily feed intake 
(FI) was assessed on a cage basis, and the overall feed conversion ratio (FCR) was evaluated as $\mathrm{kg}$ of feed per $\mathrm{kg}$ of eggs.

\subsection{Egg Quality}

Egg and eggshell quality criteria including egg weight, length, and width, shell thickness, yolk width, thick and thin albumin width, yolk height, egg white height, yolk weight, egg white weight, yolk color, and shell weight were measured at 42 and 54 weeks. From each test, 30 eggs laid between 08:00 and 12:00 were randomly chosen. Eggs were individually weighed and split on the Egg Quality Measure (EQM) plate measuring stand and the albumin height was determined. The strength of the yolk color was measured and reported using the Roche yolk fan color process. Eggshells were cleaned of any adhering albumin to determine shell weight, and the membrane was eliminated; eggshells were then dried at $37^{\circ} \mathrm{C}$ for $1 \mathrm{~h}$ and their weight was measured as a percentage of the entire egg. An assessment of egg consistency was carried out on individual eggs, equivalent to the estimated egg weight.

\subsection{Reproductive Morphological Measurements}

One bird per replicate was weighed and slaughtered at the end of the experiment. The weight of internal organs and morphology of the reproductive system were evaluated. The weight of liver, gizzard, spleen, and abdominal fat was assessed. The ovary and oviduct were also weighed, and the overall length of the oviduct was measured. The relative weight and length of oviduct portions (including vagina, uterus, isthmus, magnum, and infundibulum) were calculated [15].

\subsection{Serum Biochemical Parameters}

Blood samples were collected and centrifuged for $30 \mathrm{~min}$ at $3000 \mathrm{~g}$, and samples for serum constituent measurements were stored at $-20^{\circ} \mathrm{C}$. The quantities of total cholesterol, high-density lipoprotein (HDL), albumin, total protein, aspartate aminotransferase (AST), alanine aminotransferase (ALT), Ca, P, and glucose were analyzed spectrophotometrically (Unico UV-2000; SpectraLab Scientific Inc., San marcos, CA, USA) at a wavelength of $545 \mathrm{~nm}$ [16] using a commercial kit (Egyptian Company for Biotechnology, Cairo, Egypt). Triglyceride concentration was measured (Wako Chemicals, Richmond, VA, USA) and used as a marker of circulating low-density lipoprotein (LDL), which is an accurate and simple method to estimate the LDL production and reproductive status of domestic fowl [17].

\subsection{Yolk Chemical Analysis}

Yolk cholesterol was established in fat extracted from the yolk with a mixture of methanol and chloroform (1:2 vol:vol) [18,19]. Malondialdehyde (MDA) content of the yolk was determined colorimetrically, as described by Saleh et al. [20]. Yolk concentrations of calcium and phosphorus were evaluated by the mineral measurement method [21].

\subsection{Data Analysis}

The collected data were analyzed using the general linear model (GLM) procedure in SAS (v 9.4; SAS Institute, 2016, Gary, CA, USA). The significance of differences of means was tested using Tukey's test, and all differences were considered significant at $p<0.05$.

\section{Results}

\subsection{Performance Measurements}

As presented in Table 2, no significant effects were recorded in final BW, FI, FCR, egg weight, egg production, and egg mass of hens fed diets with low available $\mathrm{P}$ and fortified with bacterial or fungal sources of phytase compared to the control birds. 
Table 2. Effect of bacterial or fungal sources of phytase on performance in layers.

\begin{tabular}{|c|c|c|c|c|c|c|}
\hline \multirow[b]{2}{*}{ Item } & \multicolumn{4}{|c|}{ Dietary Phytase, FTU/kg * } & \multirow[b]{2}{*}{ SEM } & \multirow[b]{2}{*}{$p$-Value } \\
\hline & Control & $\begin{array}{l}\text { Quantum }^{\mathrm{TM}} \\
\text { Blue 5G }\end{array}$ & $\begin{array}{c}\text { VemoZyme }^{\circledR} F \\
5000 \text { NTP }\end{array}$ & $\begin{array}{c}\text { Yemzim }^{\circledR} \\
\text { FZ100 }\end{array}$ & & \\
\hline Initial body weight, $g$ & 1799 & 1800 & 1812 & 1814 & 11.95 & 0.7083 \\
\hline Final body weight, $g$ & 1881 & 1880 & 1893 & 1894 & 12.14 & 0.7791 \\
\hline Body weight gain, $\mathrm{g} / 12$ weeks & 82.7 & 79.7 & 81.0 & 79.3 & 4.30 & 0.9561 \\
\hline Feed intake, g/day & 106.8 & 108.5 & 104.7 & 105.0 & 1.05 & 0.4270 \\
\hline Egg weight, $g$ & 61.64 & 62.60 & 62.32 & 62.35 & 0.46 & 0.4958 \\
\hline Egg production, \% & 89.60 & 89.46 & 87.94 & 88.13 & 1.29 & 0.7163 \\
\hline Egg mass, $\mathrm{g}$ of hen ${ }^{-1}$ day $^{-1}$ & 55.22 & 55.97 & 54.82 & 54.91 & 0.81 & 0.7460 \\
\hline $\begin{array}{l}\text { Feed conversion ratio, } g \\
\text { feed/g egg }\end{array}$ & 1.94 & 1.95 & 1.91 & 1.92 & 0.02 & 0.6517 \\
\hline
\end{tabular}

Values presented are means and standard errors of 60 per treatment. * Control diet was not supplemented with phytase; other diets were supplemented with phytase sources at 5000 FTU/kg. SEM, standard error of means. NTP: Naturally Thermostable Phytase.

\subsection{Egg Quality}

The impact of bacterial and fungal phytases on egg quality characteristics of layers at 42 and 54 weeks of age are shown in Table 3. No significant variations were recorded among egg quality characteristics at 42 weeks. Both bacterial and fungal phytases increased $(p<0.05)$ shell weight and shell thickness compared to the control. Dietary supplementation with Quantum ${ }^{\mathrm{TM}}$ Blue 5G reduced $(p<0.01)$ yolk weight and increased $(p<0.05)$ white weight, while VemoZyme ${ }^{\circledR}$ F 5000 NTP and Yemzim ${ }^{\circledR}$ FZ100 did not affect these parameters.

Table 3. Effect of bacterial or fungal phytase sources on egg quality in layers.

\begin{tabular}{|c|c|c|c|c|c|c|}
\hline \multirow[b]{2}{*}{ Item } & \multicolumn{4}{|c|}{ Dietary Phytase, FTU/kg * } & \multirow[b]{2}{*}{ SEM } & \multirow[b]{2}{*}{$p$-Value } \\
\hline & Control & $\begin{array}{l}\text { Quantum }^{\mathrm{TM}} \\
\text { Blue 5G }\end{array}$ & $\begin{array}{c}\text { VemoZyme }^{\circledR} F \\
5000 \text { NTP }\end{array}$ & $\begin{array}{c}\text { Yemzim }^{\circledR} \\
\text { FZ100 }\end{array}$ & & \\
\hline \multicolumn{7}{|c|}{ At 42 weeks } \\
\hline Egg weight, g & 60.40 & 60.40 & 60.50 & 60.00 & 0.14 & 0.0816 \\
\hline Egg length, mm & 55.6 & 54.6 & 55.2 & 55.84 & 0.04 & 0.2648 \\
\hline Egg width, mm & 44.7 & 43.8 & 44.2 & 43.4 & 0.06 & 0.4348 \\
\hline Shell thickness, mm & 574.64 & 569.00 & 572.00 & 571.00 & 8.72 & 0.2639 \\
\hline Yolk width, mm & 4.01 & 3.98 & 4.14 & 4.04 & 0.07 & 0.4125 \\
\hline Thick albumin width, $\mathrm{mm}$ & 3.01 & 3.23 & 4.12 & 3.68 & 0.31 & 0.0707 \\
\hline Thin albumin width, $\mathrm{mm}$ & 2.72 & 2.74 & 3.25 & 3.52 & 0.29 & 0.1509 \\
\hline Yolk height, $\mathrm{mm}$ & $18.24^{\mathrm{a}}$ & $17.82^{a b}$ & $17.04^{\mathrm{ab}}$ & $16.50^{\mathrm{abc}}$ & 0.29 & 0.0005 \\
\hline Albumin height, $\mathrm{mm}$ & $7.31^{\mathrm{a}}$ & $7.50^{\mathrm{a}}$ & $6.46^{\mathrm{ab}}$ & $5.93^{\mathrm{ab}}$ & 0.43 & 0.0442 \\
\hline Yolk weight, g & 15.00 & 14.90 & 15.60 & 16.00 & 0.52 & 0.4086 \\
\hline White weight, $g$ & 38.00 & 37.90 & 37.70 & 36.40 & 0.60 & 0.2162 \\
\hline Shell weight, $\mathrm{g}$ & 7.00 & 7.20 & 6.80 & 7.20 & 0.25 & 0.6192 \\
\hline Yolk color, Roche fan & 6.20 & 5.80 & 6.40 & 6.20 & 0.22 & 0.2812 \\
\hline \multicolumn{7}{|c|}{ At 54 weeks } \\
\hline Egg weight, g & 64.70 & 64.80 & 64.60 & 65.30 & 0.27 & 0.2803 \\
\hline Egg length, $\mathrm{mm}$ & 5.73 & 5.61 & 5.64 & 5.63 & 0.07 & 0.1300 \\
\hline Egg width, mm & 4.46 & 4.49 & 4.47 & 4.51 & 0.02 & 0.0958 \\
\hline Shell thickness, $\mathrm{mm}$ & $527.00^{\mathrm{c}}$ & $562.96^{\mathrm{a}}$ & $551.97^{\mathrm{b}}$ & $551.63^{\mathrm{b}}$ & 9.28 & 0.0015 \\
\hline Yolk width, mm & 3.99 & 3.88 & 4.02 & 3.95 & 0.05 & 0.3038 \\
\hline Thick albumin width, $\mathrm{mm}$ & 1.92 & 2.32 & 1.78 & 2.08 & 0.29 & 0.6224 \\
\hline
\end{tabular}


Table 3. Cont.

\begin{tabular}{|c|c|c|c|c|c|c|}
\hline \multirow[b]{2}{*}{ Item } & \multicolumn{4}{|c|}{ Dietary Phytase, FTU/kg * } & \multirow[b]{2}{*}{ SEM } & \multirow[b]{2}{*}{$p$-Value } \\
\hline & Control & $\begin{array}{l}\text { Quantum }^{\mathrm{TM}} \\
\text { Blue 5G }\end{array}$ & $\begin{array}{c}\text { VemoZyme }^{\circledR} F \\
5000 \text { NTP }\end{array}$ & $\begin{array}{c}\text { Yemzim }^{\circledR} \\
\text { FZ100 }\end{array}$ & & \\
\hline Thin albumin width, $\mathrm{mm}$ & 1.57 & 1.12 & 1.74 & 1.25 & 0.31 & 0.4724 \\
\hline Yolk height, mm & 18.20 & 18.01 & 17.63 & 18.29 & 0.20 & 0.1048 \\
\hline Albumin height, $\mathrm{mm}$ & 7.90 & 8.11 & 7.60 & 8.39 & 0.40 & 0.5688 \\
\hline Yolk weight, g & $16.20^{\mathrm{a}}$ & $14.30^{\mathrm{b}}$ & $15.60^{a b}$ & $15.10^{a b}$ & 0.37 & 0.0077 \\
\hline White weight, g & $40.70^{\mathrm{b}}$ & $42.80^{\mathrm{a}}$ & $41.70^{a b}$ & $42.60 \mathrm{ab}$ & 0.51 & 0.0236 \\
\hline Shell weight, $g$ & $6.40^{\mathrm{b}}$ & $7.97^{\mathrm{a}}$ & $7.20^{\mathrm{a}}$ & $7.89 a$ & 0.22 & 0.04092 \\
\hline Yolk color, Roche fan & 6.60 & 6.90 & 6.50 & 6.60 & 0.15 & 0.2839 \\
\hline
\end{tabular}

Values presented are means and their standard errors of 30 eggs per treatment. ${ }^{\mathrm{a}, \mathrm{b}, \mathrm{c}}$ Mean values followed by different letters in the same row are significantly different $(p<0.05)$. ${ }^{*}$ Control diet was not supplemented with phytase; other diets were supplemented with phytase sources at $5000 \mathrm{FTU} / \mathrm{kg}$. SEM, standard error of means. NTP: Naturally Thermostable Phytase.

\subsection{Serum Biochemical Parameters}

Results concerning the impact of bacterial and fungal phytases on biochemical blood indices of laying hens are shown in Table 4. Dietary supplements did not significantly alter serum protein fractions, lipid profile, and liver enzymes. Calcium and P levels were increased $(p<0.05)$ in birds supplemented with bacterial and fungal phytases.

Table 4. Effect of bacterial or fungal phytase sources on serum biochemical parameters of layers at 54 weeks of age.

\begin{tabular}{|c|c|c|c|c|c|c|}
\hline \multirow[b]{2}{*}{ Item } & \multicolumn{4}{|c|}{ Dietary Phytase, FTU/kg * } & \multirow[b]{2}{*}{ SEM } & \multirow[b]{2}{*}{$p$-Value } \\
\hline & Control & $\begin{array}{l}\text { Quantum }^{\mathrm{TM}} \\
\text { Blue 5G }\end{array}$ & $\begin{array}{c}\text { VemoZyme }^{\circledR} \text { F } \\
5000 \text { NTP }\end{array}$ & $\begin{array}{c}\text { Yemzim }^{\circledR} \\
\text { FZ100 }\end{array}$ & & \\
\hline Total protein, $\mathrm{mg} / \mathrm{dL}$ & 5.23 & 5.55 & 5.98 & 6.35 & 0.35 & 0.1640 \\
\hline Albumin, mg/dL & 2.05 & 2.23 & 2.35 & 2.43 & 0.14 & 0.3045 \\
\hline Glucose, mg/dL & 148.00 & 149.75 & 142.50 & 135.25 & 9.11 & 0.6806 \\
\hline ALT, U/I & 3.75 & 3.60 & 2.93 & 3.63 & 0.40 & 0.4754 \\
\hline AST, U/I & 205.00 & 247.75 & 227.25 & 226.50 & 21.63 & 0.5973 \\
\hline Total cholesterol, mg/dL & 136.50 & 138.50 & 122.50 & 125.25 & 9.09 & 0.5317 \\
\hline Triglyceride, mg/dL & 65.72 & 56.93 & 57.68 & 51.50 & 5.93 & 0.9100 \\
\hline $\mathrm{HDL}, \mathrm{mg} / \mathrm{dL}$ & 31.50 & 29.00 & 26.25 & 29.25 & 2.72 & 0.6117 \\
\hline $\mathrm{LDL}, \mathrm{mg} / \mathrm{dL}$ & 69.00 & 76.50 & 81.75 & 86.00 & 8.62 & 0.5581 \\
\hline Calcium, mg/dL & $13.10^{b}$ & $15.98^{a}$ & $14.65^{\mathrm{ab}}$ & $15.05^{\mathrm{a}}$ & 1.00 & 0.0472 \\
\hline Phosphorus, mg/dL & $5.08^{b}$ & $6.78^{\mathrm{a}}$ & $6.48^{\mathrm{a}}$ & $6.35^{\mathrm{a}}$ & 0.32 & 0.0220 \\
\hline
\end{tabular}

Values presented are means and standard errors of 15 samples per treatment. ${ }^{a, b}$ Mean values followed by different letters in the same row are significantly different $(p<0.05)$. ${ }^{*}$ Control diet was not supplemented with phytase; other diets were supplemented with phytase sources at $5000 \mathrm{FTU} / \mathrm{kg}$. AST, aspartate aminotransferase; ALT, alanine aminotransferase; HDL, high-density lipoprotein; LDL, low-density lipoprotein; SEM, standard error of means. NTP: Naturally Thermostable Phytase.

\subsection{Reproductive Morphology Measurements}

The data presented in Table 5 show that dietary supplementation with bacterial or fungal phytases did not affect the relative weights of ovary, liver, gizzard, and spleen. The length and relative weight of the oviduct and its segments were also not altered, except for infundibulum weight $(\%)$, which was reduced $(p<0.05)$ in groups treated with Quantum ${ }^{\mathrm{TM}}$ Blue 5G and Yemzim ${ }^{\circledR}$ FZ100 compared to the control group. 
Table 5. Effect of bacterial or fungal phytase sources on internal organ weight and reproductive morphology of layers at 54 weeks of age.

\begin{tabular}{|c|c|c|c|c|c|c|}
\hline \multirow[b]{2}{*}{ Item } & \multicolumn{4}{|c|}{ Dietary Phytase, FTU/kg * } & \multirow[b]{2}{*}{ SEM } & \multirow[b]{2}{*}{$p$-Value } \\
\hline & Control & $\begin{array}{l}\text { Quantum }_{\text {Blue 5G }}^{\mathrm{TM}} \\
\text {. }\end{array}$ & $\begin{array}{c}\text { VemoZyme }^{\circledR} \mathrm{F} \\
5000 \mathrm{NTP}\end{array}$ & $\begin{array}{c}\text { Yemzim }^{\circledR} \\
\text { FZ100 }\end{array}$ & & \\
\hline Live body weight, $g$ & 1834.40 & 1759.80 & 1802.80 & 1820.40 & 19.96 & 0.0854 \\
\hline Liver weight, g/100 g BW & 1.830 & 1.865 & 1.783 & 1.845 & 0.097 & 0.9204 \\
\hline Gizzard weight, g/100 g BW & 1.079 & 1.071 & 1.067 & 1.080 & 0.048 & 0.4604 \\
\hline Spleen weight, g/100 g BW & 0.063 & 0.063 & 0.067 & 0.064 & 0.0011 & 0.2254 \\
\hline Fat weight, g/100 g BW & 3.595 & 3.602 & 3.585 & 3.579 & 0.174 & 0.8817 \\
\hline Ovary weight, $\%$ & 37.60 & 40.00 & 41.60 & 47.60 & 2.74 & 0.1043 \\
\hline Oviduct weight, $\%$ & 69.20 & 68.60 & 72.00 & 62.40 & 3.95 & 0.3972 \\
\hline Infundibulum weight, $\%$ & $2.60^{\mathrm{a}}$ & $1.60^{b}$ & $2.00^{a b}$ & $1.00^{b}$ & 0.36 & 0.0405 \\
\hline Magnum weight, \% & 32.00 & 29.40 & 30.40 & 27.60 & 2.41 & 0.6328 \\
\hline Isthmus weight, $\%$ & 6.40 & 7.00 & 7.20 & 4.60 & 0.86 & 0.1717 \\
\hline Uterus weight, \% & 23.80 & 23.40 & 25.60 & 23.80 & 2.02 & 0.8685 \\
\hline Vagina weight, $\%$ & 4.20 & 6.60 & 5.40 & 5.60 & 0.95 & 0.3889 \\
\hline Oviduct length, $\mathrm{mm}$ & 70.60 & 75.20 & 73.00 & 69.20 & 2.84 & 0.4756 \\
\hline Infundibulum length, $\mathrm{mm}$ & 10.00 & 9.00 & 10.30 & 8.10 & 1.06 & 0.4666 \\
\hline Magnum length, mm & 36.00 & 40.40 & 37.00 & 39.30 & 2.24 & 0.5511 \\
\hline Isthmus length, $\mathrm{mm}$ & $11.90^{\mathrm{ab}}$ & $12.30^{a}$ & $13.20^{\mathrm{a}}$ & $8.40^{b}$ & 0.91 & 0.0095 \\
\hline Uterus length, $\mathrm{mm}$ & 7.00 & 7.10 & 7.80 & 7.00 & 0.49 & 0.6170 \\
\hline Vagina length, $\mathrm{mm}$ & 4.30 & 5.40 & 4.60 & 4.90 & 0.49 & 0.4594 \\
\hline
\end{tabular}

Values presented are means and their standard errors of 30 eggs per treatment. ${ }^{\mathrm{a}, \mathrm{b}}$ Mean values followed by different letters in the same row are significantly different $(p<0.05) .{ }^{*}$ Control diet was not supplemented with phytase; other diets were supplemented with phytase sources at 5000 FTU $/ \mathrm{kg}$. SEM, standard error of means; BW, body weight. NTP: Naturally Thermostable Phytase.

\subsection{Yolk Chemical Analysis}

As shown in Table 6, the MDA content of yolk was numerically reduced in Quantum ${ }^{\mathrm{TM}}$ Blue 5G and Yemzim ${ }^{\circledR F Z 100 ~ t r e a t e d ~ g r o u p s, ~ w h i l e ~ c h o l e s t e r o l ~ c o n t e n t ~ w a s ~ s u b s t a n t i a l l y ~}$ $(p<0.01)$ reduced in all treated groups. Ca and $\mathrm{P}$ concentrations in the yolk were elevated $(p<0.05)$ in Quantum ${ }^{\mathrm{TM}}$ Blue 5G and Yemzim®FZ100 compared to the control group.

Table 6. Effect of bacterial or fungal phytase sources on calcium, phosphorus, cholesterol, and malondialdehyde (MDA) contents in egg yolk at 54 weeks of age.

\begin{tabular}{|c|c|c|c|c|c|c|}
\hline \multirow[b]{2}{*}{ Item } & \multicolumn{4}{|c|}{ Dietary Phytase, FTU/kg * } & \multirow[b]{2}{*}{ SEM } & \multirow[b]{2}{*}{$\begin{array}{c}p- \\
\text { Values }\end{array}$} \\
\hline & Control & $\begin{array}{l}\text { Quantum }^{\mathrm{TM}} \\
\text { Blue 5G }\end{array}$ & $\begin{array}{c}\text { VemoZyme }^{\circledR} F \\
5000 \text { NTP }\end{array}$ & $\begin{array}{l}\text { Yemzim }^{\circledR} \\
\text { FZ100 }\end{array}$ & & \\
\hline $\mathrm{MDA}, \mathrm{nmol} / \mathrm{g}$ & 0.229 & 0.188 & 0.202 & 0.179 & 0.013 & 0.069 \\
\hline Cholesterol, g/g & $14.06^{\mathrm{a}}$ & $10.96^{c}$ & $12.38^{b}$ & $10.77^{c}$ & 0.35 & 0.003 \\
\hline Calcium, mg/100 g & $113.7^{b}$ & $132.2^{\mathrm{a}}$ & $121.3^{\mathrm{ab}}$ & $131.7^{\mathrm{a}}$ & 3.5 & 0.042 \\
\hline Phosphorus, mg/100 g & $267.7^{b}$ & $301.7^{\mathrm{a}}$ & $279.3^{\mathrm{ab}}$ & $304.6^{\mathrm{a}}$ & 6.8 & 0.008 \\
\hline
\end{tabular}

Values presented are means and their standard errors of 30 eggs per treatment. ${ }^{a}, \mathrm{~b}, \mathrm{c}$ Mean values followed by different letters in the same row are significantly different $(p<0.05)$. ${ }^{*}$ Control diet was not supplemented with phytase; other diets were supplemented with phytase sources at 5000 FTU $/ \mathrm{kg}$. SEM, standard error of means. NTP: Naturally Thermostable Phytase.

\section{Discussion}

The beneficial role of bacterial and fungal phytases in alleviating the negative impact of dietary P deficiency in poultry has been well documented $[10,22]$. This study proposes that phytase can hydrolyze phosphoester bonds of phytates and release nutrients, which improves their utilization. The results of the present study revealed no significant gaps in productivity efficiency between layers fed the control diet and those fed diets with low available $\mathrm{P}$ fortified with bacterial and fungal phytases, which appears to support the conclusions of previous studies. Our findings follow those of Shet et al. [23], Tischler et al. [24], and Żyła et al. [25], who described that dietary addition of exogenous phytases at 250, 300, 
and $500 \mathrm{FTU} / \mathrm{kg}$ feed with normal or low levels of available P had no effect on egg number, FI, and FCR. On the contrary, Jalal and Scheideler [26] reported that feeding on a low $0.01 \%$ non-phytate $\mathrm{P}$ diet supplemented with commercial phytase ( 250 and $300 \mathrm{FTU} / \mathrm{kg}$ ) improved the FI, FCR, and egg mass of layers. Moreover, in the present study, we found that no discrepancies between bacterial and fungal phytase sources were noticed. Yan et al. [27], Sands et al. [28], and Stahl et al. [29] showed comparable results in young pigs, broilers, and aged laying hens and explained that these findings were due to improper gastrointestinal $\mathrm{pH}$, elaborating the potential catalytic differences among phytase sources. Additionally, it has been stated that changes in the gastrointestinal maturation of laying hens that occur as the birds get older may affect the potential activity of bacterial and fungal phytases [30,31].

Egg quality characteristics of hens fed diets with low available P and microbial phytases were not different than those fed diets with normal available P. However, eggshell quality criteria (thickness and weight) were improved in treated layers compared to controls. Inconsistency was noticed in the results of egg quality criteria as affected by dietary phytase supplementation. On the one hand, Mohammed et al. [32] reported that supplementation with phytase in layers' diets had no significant effect on egg quality measurements. Lucky et al. [33], Panda et al. [34], and Cabuk et al. [35] noted no changes in eggshell weight and thickness with various dietary phytase levels. On the other hand, it has been stated that low levels of $\mathrm{Ca}$ and available $\mathrm{P}$ in diets without phytase supplementation reduced eggshell weight [36,37]. Liu et al. [38] demonstrated that eggshell thickness was improved by dietary supplementation with $\mathrm{Ca}, \mathrm{P}$, and phytase. Furthermore, as reported by Żyła et al. [39], Hughes et al. [40], and Jalal and Scheideler [26], dietary phytase was effective in enhancing eggshell quality when laying hens received diets with inadequate non-phytate $P$. The increased eggshell quality may be attributed to increased nutrient digestibility associated with phytase supplementation and better utilization of $\mathrm{P}$ by hens [27].

Reproductive morphology measurements were not influenced by feeding on diets with low available P complemented with bacterial or fungal phytase sources. No previous investigations evaluated the impact of microbial phytases on oviduct and ovarian morphology. The potential role of microbial phytases in maintaining reproductive system morphology in hens fed diets with low available P could be through their ability to reduce endogenous amino acid flow, enhance the availability of dietary energy, and enhance the digestibility of protein, phosphorus, and amino acids [41]. Microbial phytases can also dephosphorylate insoluble phytate salts and liberate minerals such as $\mathrm{Zn}, \mathrm{Mn}, \mathrm{Fe}, \mathrm{Cu}$, and $\mathrm{Mg}[42,43]$, which might be involved in regulating the development of the oviduct and ovary in layers [15]. Xie et al. [44] confirmed this assumption and documented that $\mathrm{Mn}$ has a vital role in regulating hormones that participate in egg production and ovarian development in broiler breeder hens.

Dietary inclusion of bacterial or fungal phytases increased serum and yolk levels of P compared to the control. These data are in agreement with those of Yan et al. [27], who noticed an elevation in serum $\mathrm{Ca}$ and $\mathrm{P}$ values of layers fed diets with phytase and found that these levels were positively correlated with nutrient digestibility. Rama-Rao et al. [45] also reported a linear increase in serum $P$ in response to phytase addition. In contrast, serum Ca was not elevated linearly, which might be attributed to the antagonistic impact of serum $\mathrm{P}$ and $\mathrm{Ca}$. On the contrary, no significant differences in the P and Ca contents of egg yolk were noticed with phytase addition [46]. Moreover, Viveros et al. [47] and Sebastian et al. [48] documented that phytase supplementation of low non-phytate P diets reduced plasma $\mathrm{Ca}$ and increased plasma $\mathrm{P}$ levels. The increased serum $\mathrm{Ca}$ and $\mathrm{P}$ levels can be attributed to the ability of microbial phytases to dephosphorylate phosphoester bonds of phytates and insoluble phytate salts and release P [42,43]. Moreover, it has been reported that feeding on low P diets led to elevate plasma levels of ionized Ca [49]. Generally, numerous factors can affect $\mathrm{Ca}$ and $\mathrm{P}$ metabolism and deposition in the egg yolk, such as the age and genetic line of the birds and their physiological status. 
In the present study, cholesterol concentration in egg yolk was reduced in groups with microbial phytase supplementation. Our results are in line with those of Saleh [50], who reported that the content of total cholesterol in egg yolk was decreased by dietary supplementation with bacterial phytase in low P diets. Furthermore, Żyła et al. [39] also reported that yolk cholesterol was reduced in Hi-sex laying hens fed diets with phytase. The authors suggested that the increased content of unsaturated fatty acids in egg yolk by phytase inclusion might be the cause of the reduction in cholesterol. However, this finding requires more detailed research, mainly because similar reductions in probiotics have been observed $[19,51-54]$, and probiotics are known to have the ability to produce phytase $[55,56]$.

\section{Conclusions}

The results of the present study demonstrate that $5000 \mathrm{FTU} / \mathrm{kg}$ dietary supplementation with bacterial (E. coli) or fungal (Aspergillus niger and Trichodermareesei) sources of phytase is capable of maintaining the productive performance, reproductive morphology, and egg quality of layers with supplementation of 30\% less available P. Eggshell quality and yolk cholesterol were also improved in groups fed bacterial or fungal supplemented diets. No obvious differences were noticed in the ability of bacterial and fungal phytase to liberate phytate-bound complexes when supplemented in layers' diets with $0.32 \%$ available phosphorus. Altogether, our findings elucidate that feeding laying hens any studied phytase source at $5000 \mathrm{FTU} / \mathrm{kg}$ can be efficient as a substitute for inorganic phosphorus on the commercial scale.

Author Contributions: A.A.S. and M.E., M.M.S., and R.Y.N.E. designed the study plan, collected literature, and drafted the manuscript; A.A.S., M.E., M.M.S., A.-M.E.A.-M., H.E., and R.Y.N.E. helped in carrying out the research work and conducting data analysis, and assisted in the writing of the manuscript; A.A.S., M.E., M.S., A.-M.E.A.-M., H.E., R.Y.N.E., R.Y.N.E., M.H.A., H.E. and M.M.S. provided technical help in writing the manuscript. All authors have read and approved the final manuscript.

Funding: This study was supported by the Taif University Researchers Supporting Project (TURSP2020/09), Taif University, Taif, Saudi Arabia.

Institutional Review Board Statement: The study was conducted according to the guidelines of the Declaration of Helsinki, and approved by the Ethics Committee of the Local Experimental Animals Treatment Committee and operated following the guidelines of Kafrelsheik University, Egypt (number 4/2016EC).

Data Availability Statement: Data supporting this study's findings are available by fair request from the corresponding author.

Acknowledgments: The authors wish to acknowledge the helpful suggestions of members of the poultry production faculty of agriculture, Kafrelsheikh University, Egypt. We also appreciate and thank Taif University, Saudi Arabia, for financial support through its Researchers Supporting Project (TURSP-2020/09).

Conflicts of Interest: The authors declare no conflict of interest.

\section{References}

1. Kumar, V.; Sinha, A.K.; Makkar, H.P.; De Boeck, G.; Becker, K. Phytate and phytase in fish nutrition. J. Anim. Physiol. Anim. Nutr. 2012, 96, 335-364. [CrossRef]

2. Lalpanmawia, H.; Elangovan, A.; Sridhar, M.; Shet, D.; Ajith, S.; Pal, D. Efficacy of phytase on growth performance, nutrient utilization and bone mineralization in broiler chicken. Anim. Feed Sci. Technol. 2014, 192, 81-89. [CrossRef]

3. Woyengo, T.; Nyachoti, C. Anti-nutritional effects of phytic acid in diets for pigs and poultry-Current knowledge and directions for future research. Can. J. Anim. Sci. 2013, 93, 9-21. [CrossRef]

4. Morgan, N.K.; Walk, C.L.; Bedford, M.R.; Scholey, D.V.; Burton, E.J. Effect of feeding broilers diets differing in susceptible phytate content. Anim. Nut. 2016, 2, 33-39. [CrossRef]

5. Withers, P.; Davidson, I.; Foy, R. The contribution of agricultural phosphorus to eutrophication. The fertilizer society. Nawozy Nawożenie 2002, 4, 20-48. 
6. Dersjant-Li, Y.; Awati, A.; Schulze, H.; Partridge, G. Phytase in non-ruminant animal nutrition: A critical review on phytase activities in the gastrointestinal tract and influencing factors. J. Sci. Food Agric. 2015, 95, 878-896. [CrossRef] [PubMed]

7. Cromwell, G. ASAS centennial paper: Landmark discoveries in swine nutrition in the past century. J. Anim. Sci. 2009, 87, 778-792. [CrossRef]

8. Han, J.; Yang, X.; Qu, H.; Xu, M.; Zhang, T.; Li, W.; Yao, J.; Liu, Y.; Shi, B.; Zhou, Z. Evaluation of equivalency values of microbial phytase to inorganic phosphorus in 22-to 42-day-old broilers. J. Appl. Poult. Res. 2009, 18, 707-715. [CrossRef]

9. Zyła, K.; Mika, M.; Stodolak, B.; Wikiera, A.; Koreleski, J.; Ŝwiątkiewicz, S. Towards complete dephosphorylation and total conversion of phytates in poultry feeds. Poult. Sci. 2004, 83, 1175-1186. [CrossRef]

10. Selle, P.H.; Ravindran, V. Microbial phytase in poultry nutrition. Anim. Feed Sci. Technol. 2007, 135, 1-41. [CrossRef]

11. Bedford, M.R.; Partridge, G.G. Enzymes in Farm Animal Nutrition; CABI: Wallingford, UK, 2010.

12. Mullaney, E.J.; Ullah, A.H.; Turner, B.; Richardson, A.; Mullaney, E. Phytases: Attributes, catalytic mechanisms and applications. In Inositol Phosphates: Linking Agriculture and the Environment; CABI: Wallingford, UK, 2007; pp. 97-110.

13. Adedokun, S.; Sands, J.; Adeola, O. Determining the equivalent phosphorus released by an Escherichia coli-derived phytase in broiler chicks. Can. J. Anim. Sci. 2004, 84, 437-444. [CrossRef]

14. Available online: http:/ / cabobo.eu/attachments/File/Management_Guide.pdf (accessed on 5 January 2021).

15. Saleh, A.A.; Eltantawy, M.S.; Gawish, E.M.; Younis, H.H.; Amber, K.A.; Abd El-Moneim, A.E.-M.E.; Ebeid, T.A. Impact of Dietary Organic Mineral Supplementation on Reproductive Performance, Egg Quality Characteristics, Lipid Oxidation, Ovarian Follicular Development, and Immune Response in Laying Hens Under High Ambient Temperature. Biol. Trace Elem. Res. 2019, 195, 506-514. [CrossRef] [PubMed]

16. Saleh, A.A.; Ahmed, E.A.; Ebeid, T.A. The impact of phytoestrogen source supplementation on reproductive performance, plasma profile, yolk fatty acids and antioxidative status in aged laying hens. Reprod. Domest. Anim. 2019, 54, 846-854. [CrossRef] [PubMed]

17. Ebeid, T.; Eid, Y.; El-Abd, E.; El-Habbak, M. Effects of catecholamines on ovary morphology, blood concentrations of estradiol-17 $\beta$, progesterone, zinc, triglycerides and rate of ovulation in domestic hens. Theriogenology 2008, 69, 870-876. [CrossRef] [PubMed]

18. Saleh, A.A. Effects of fish oil on the production performances, polyunsaturated fatty acids and cholesterol levels of yolk in hens. Emir. J. Food Agric. 2013, 25, 605-612. [CrossRef]

19. Abd El-Moneim, A.E.; Sabic, E.M. Beneficial effect of feeding olive pulp and Aspergillus awamori on productive performance, egg quality, serum/yolk cholesterol and oxidative status in laying Japanese quails. J. Anim. Feed Sci. 2019, 28, 52-61. [CrossRef]

20. Saleh, A.A.; Kirrella, A.A.; Dawood, M.; Ebeid, T.A. Effect of dietary inclusion of cumin seed oil on the performance, egg quality, immune response and ovarian development in laying hens under high ambient temperature. J. Anim. Physiol. Anim. Nutr. 2019, 103, 1810-1817. [CrossRef]

21. AOAC. Official Methods of Analysis of AOAC, 16th ed.; AOAC: Gaithersburg, MD, USA, 2000.

22. Wu, G.; Liu, Z.; Bryant, M.; Roland, D., Sr. Comparison of Natuphos and Phyzyme as phytase sources for commercial layers fed corn-soy diet. Poult. Sci. 2006, 85, 64-69. [CrossRef]

23. Shet, D.; Ghosh, J.; Ajith, S.; Awachat, V.B.; Elangovan, A.V. Efficacy of dietary phytase supplementation on laying performance and expression of osteopontin and calbindin genes in eggshell gland. Anim. Nut. 2018, 4, 52-58. [CrossRef]

24. Tischler, A.; Halas, V.; Tossenberger, J. Effect of dietary NPP level and phytase supplementation on the laying performance over one year period. Poljoprivreda 2015, 21, 68-72. [CrossRef]

25. Żyła, K.; Mika, M.; Świątkiewicz, S.; Koreleski, J.; Piironen, J. Effects of phytase B on laying performance, eggshell quality and on phosphorus and calcium balance in laying hens fed phosphorus-deficient maize-soybean meal diets. Czech J. Anim. Sci. 2011, 56, 406-413. [CrossRef]

26. Jalal, M.; Scheideler, S. Effect of supplementation of two different sources of phytase on egg production parameters in laying hens and nutrient digestiblity. Poult. Sci. 2001, 80, 1463-1471. [CrossRef] [PubMed]

27. Yan, L.; Zhou, T.; Jang, H.; Hyun, Y.; Kim, H.; Kim, I. Comparative effects of phytase derived from Escherichia coli and Aspergillus niger in sixty eight-week-old laying hens fed corn-soy diet. Asian Australas. J. Anim. Sci. 2009, 22, 1391-1399. [CrossRef]

28. Sands, J.; Stilborn, R.; Berg, J.; Salmon, R. Comparative efficacy of two microbial phytases for improving performance in broilers fed low-P diets. Poult. Sci. 2003, 82, 118.

29. Stahl, C.; Roneker, K.; Thornton, J.; Lei, X. A new phytase expressed in yeast effectively improves the bioavailability of phytate phosphorus to weanling pigs. J. Anim. Sci. 2000, 78, 668-674. [CrossRef] [PubMed]

30. Carlos, A.; Edwards, H., Jr. The effects of 1, 25-dihydroxycholecalciferol and phytase on the natural phytate phosphorus utilization by laying hens. Poult. Sci. 1998, 77, 850-858. [CrossRef] [PubMed]

31. Marounek, M.; Skřivan, M.; Dlouhá, G.; Břeňová, N. Availability of phytate phosphorus and endogenous phytase activity in the digestive tract of laying hens 20 and 47 weeks old. Anim. Feed Sci. Technol. 2008, 146, 353-359. [CrossRef]

32. Mohammed, K.; Toson, M.; Hassanien, H.; Soliman, M.; El-nagar, S.H. Effects of phytase supplementation on performance and egg quality of laying hens fed diets containing rice bran. Egypt. Poult. Sci. J. 2010, 30, 649-659.

33. Lucky, N.; Howlider, M.; Alam, M.; Ahmed, M. Effect of dietary exogenous phytase on laying performance of chicken at older ages. Bangladesh J. Anim. Sci. 2014, 43, 52-55. [CrossRef]

34. Panda, A.; Rama Rao, S.; Raju, M.; Bhanja, S. Effect of microbial phytase on production performance of White Leghorn layers fed on a diet low in non-phytate phosphorus. Br. Poult. Sci. 2005, 46, 464-469. [CrossRef] [PubMed] 
35. Cabuk, M.; Bozkurt, M.; Kyrkpynar, F.; Ozkul, H. Effect of phytase supplementation of diets with different levels of phosphorus on performance and egg quality of laying hens in hot climatic conditions. S. Afr. J. Anim. Sci. 2004, 34, 13-17. [CrossRef]

36. Ziaei, N.; Shivazad, M.; Mirhadi, S.; Gerami, A. Effects of reduced calcium and phosphorous diets supplemented with phytase on laying performance of hens. Pak. J. Biol. Sci. PJBS 2009, 12, 792-797. [CrossRef] [PubMed]

37. Lim, H.; Namkung, H.; Paik, I. Effects of phytase supplementation on the performance, egg quality, and phosphorous excretion of laying hens fed different levels of dietary calcium and nonphytate phosphorous. Poult. Sci. 2003, 82, 92-99. [CrossRef] [PubMed]

38. Liu, N.; Liu, G.; Li, F.; Sands, J.; Zhang, S.; Zheng, A.; Ru, Y. Efficacy of phytases on egg production and nutrient digestibility in layers fed reduced phosphorus diets. Poult. Sci. 2007, 86, 2337-2342. [CrossRef] [PubMed]

39. Żyła, K.; Mika, M.; Duliński, R.; Świątkiewicz, S.; Koreleski, J.; Pustkowiak, H.; Piironen, J. Effects of inositol, inositol-generating phytase B applied alone, and in combination with 6-phytase A to phosphorus-deficient diets on laying performance, eggshell quality, yolk cholesterol, and fatty acid deposition in laying hens. Poult. Sci. 2012, 91, 1915-1927. [CrossRef] [PubMed]

40. Hughes, A.; Dahiya, J.; Wyatt, C.; Classen, H. The efficacy of quantum phytase in a forty-week production trial using white leghorn laying hens fed corn-soybean meal-based diets. Poult. Sci. 2008, 87, 1156-1161. [CrossRef]

41. Ravindran, V.; Cowieson, A.; Selle, P. Influence of dietary electrolyte balance and microbial phytase on growth performance, nutrient utilization, and excreta quality of broiler chickens. Poult. Sci. 2008, 87, 677-688. [CrossRef]

42. Bedford, M.A.; Schulze, H. Exogenous enzymes for pigs and poultry. Nutr. Res. Rev. 1998, 11, 91-114. [CrossRef] [PubMed]

43. Liu, B.-L.; Rafiq, A.; Tzeng, Y.-M.; Rob, A. The induction and characterization of phytase and beyond. Enzym. Microb. Technol. 1998, 22, 415-424. [CrossRef]

44. Xie, J.; Tian, C.; Zhu, Y.; Zhang, L.; Lu, L.; Luo, X. Effects of inorganic and organic manganese supplementation on gonadotropinreleasing hormone-I and follicle-stimulating hormone expression and reproductive performance of broiler breeder hens. Poult. Sci. 2014, 93, 959-969. [CrossRef]

45. Rama-Rao, S.; Reddy, V.R.; Reddy, V.R. Enhancement of phytate phosphorus availability in the diets of commercial broilers and layers. Anim. Feed Sci. Technol. 1999, 79, 211-222. [CrossRef]

46. Vargas-Rodríguez, L.M.; Morales-Barrera, J.E.; Herrera-Haro, J.G.; Antonio-Bautista, J.; López-Pozos, R.; Hernández-Sánchez, D. Effect of Citric Acid, Phytase and Calcium Levels on the Calcium and Phosphorus Content in Egg: Yolk-Albumen and Shell, Yolk Color and Egg Quality in Diets of Laying Hens. Food Nutr. Sci. 2016, 7, 1364-1374. [CrossRef]

47. Viveros, A.; Brenes, A.; Arija, I.; Centeno, C. Effects of microbial phytase supplementation on mineral utilization and serum enzyme activities in broiler chicks fed different levels of phosphorus. Poult. Sci. 2002, 81, 1172-1183. [CrossRef] [PubMed]

48. Sebastian, S.; Touchburn, S.; Chavez, E.; Lague, P. The effects of supplemental microbial phytase on the performance and utilization of dietary calcium, phosphorus, copper, and zinc in broiler chickens fed corn-soybean diets. Poult. Sci. 1996, 75, 729-736. [CrossRef]

49. Taylor, T.G.; Dacke, C.G. Calcium metabolism and its regulation. In Physiology and Biochemistry of the Domestic Fowl; Freeman, B.M., Ed.; Academic Press: London, UK, 1984; pp. 126-170.

50. Saleh, A.A. Influence of Escherichia coli 6-phytase supplementation on performance and egg quality in Hi-sex laying hens fed phosphorus deficient diets. Egypt. Poult. Sci. 2017, 37, 1105-1117.

51. Abdel-Moneim, A.-M.E.; Selim, D.A.; Basuony, H.A.; Sabic, E.M.; Saleh, A.A.; Ebeid, T.A. Effect of dietary supplementation of Bacillus subtilis spores on growth performance, oxidative status and digestive enzyme activities in Japanese quail birds. Trop. Anim. Health Prod. 2020, 52, 671-680. [CrossRef]

52. Saleh, A.A.; Abudabos, A.M.; Ali, M.H.; Ebeid, T.A. The effects of replacing corn with low-tannin sorghum in broiler's diet on growth performance, nutrient digestibilities, lipid peroxidation and gene expressions related to growth and antioxidative properties. J. Appl. Anim. Res. 2019, 47, 532-539. [CrossRef]

53. Saleh, A.A.; Kirrella, A.A.; Abdo, S.E.; Mousa, M.M.; Badwi, N.A.; Ebeid, T.A.; Nada, A.L.; Mohamed, M.A. Effects of Dietary Xylanase and Arabinofuranosidase Combination on the Growth Performance, Lipid Peroxidation, Blood Constituents, and Immune Response of Broilers Fed Low-Energy Diets. Animals 2019, 9, 467. [CrossRef] [PubMed]

54. Abd El-Hack, M.E.; El-Saadony, M.T.; Shafi, M.E.; Qattan, S.Y.; Batiha, G.E.; Khafaga, A.F.; Abdel-Moneim, A.M.E.; Alagawany, M. Probiotics in poultry feed: A comprehensive review. J. Anim. Physiol. Anim. Nutr. 2020, 104, 1835-1850. [CrossRef]

55. Saleh, A.A.; El-Far, A.H.; Abdel-Latif, M.A.; Emam, M.A.; Ghanem, R.; Abd El-Hamid, H.S. Exogenous dietary enzyme formulations improve growth performance of broiler chickens fed a low-energy diet targeting the intestinal nutrient transporter genes. PLOS ONE 2018, 13, e0198085. [CrossRef]

56. Haros, M.; Bielecka, M.; Honke, J.; Sanz, Y. Myo-inositol hexakisphosphate degradation by Bifidobacterium infantis ATCC 15697. Int. J. Food Microbiol. 2007, 117, 76-84. [CrossRef] [PubMed] 